\title{
Inhibitive Effect of Urea and Urea Derivatives on the Corrosion of Silver in Acetic Acid Solutions
}

\author{
S. Abd El Wanees ${ }^{1,2, *},{ }^{1}$ A.M.A Shehata ${ }^{3}$ M. Barakat ${ }^{1}$ and A. Hathoot ${ }^{4}$
}

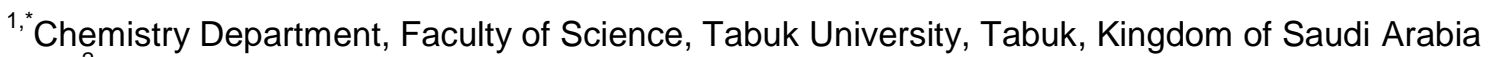

${ }^{2}$ Chemistry Department, Faculty of Science, Zagazig University, Zagazig 44519, Egypt

Corresponding author, E-mail: s_wanees@yahoo.com

${ }^{3}$ Chemistry Department, Faculty of Education 45111, Suez Canal University, Al-Arish, Egypt

${ }^{4}$ Department of Chemistry, Faculty of Science, Menoufia University, Menoufia, Egypt

\section{ABStRact}

The corrosion of silver in acetic acid was studied using potentiodynamic polarization technique in absence and presence of different concentrations of urea, thiourea and $\mathrm{N}$-allylthiourea. The inhibition efficiency was found to depend on both the inhibitor type and concentration. The inhibitive action of these compounds is based on the formation of salt complex and/or the adsorption of the protonated species on the metal surface according to Temkin's isotherm. The thermodynamic parameters $K_{\text {ads }}$ and $\Delta G^{\circ}$ ads for the adsorption process are calculated and discussed.

Keywords: Silver; Acetic acid; Corrosion inhibition; Potentiodynamic polarization and Temkin isotherm.

\section{Council for Innovative Research}

Peer Review Research Publishing System

Journal: Journal of Advances in Chemistry

Vol. 6, No. 2

editor@cirworld.com

www.cirworld.com, member.cirworld.com 


\section{INTRODUCTION}

Acid solutions are widely used in industry, e.g., chemical cleaning, descaling and pickling, which leads to corrosive attack. Therefore, the consumption of inhibitors to reduce corrosion has increased in recent years. The corrosion control by inhibitors is one of the most common, effective and economic methods to protect metals in acid media [1, 2].

The majority of the well-known inhibitors are organic compounds containing heteroatoms, such as oxygen, nitrogen or sulphur, and multiple bonds, which allow an adsorption on the metal surface [3, 4]. It has been observed that the adsorption of these inhibitors depends on the physico-chemical properties of the functional groups and the electron density at the donor atom. The adsorption process occurs due to the interaction of the lone pair and/or $\pi$-orbital's of inhibitor with d-orbital's of the metal surface atoms, which evokes a greater adsorption of the inhibitor molecules onto the surface, leading to the formation of a corrosion protection film [5-7]. The adsorption is also influenced by the structure and the charge of the metal surface, and the type of testing electrolyte [8-11]. The choice of effective inhibitors is based on their mechanism of action and electron-donating ability. Urea and their derivatives are well known as corrosion inhibitors and can effectively protect various metals from corrosion [12-14].

According to Hoar and Holliday [15] inhibitor molecules may adsorb to a different extent at different types of surface site and influence the anodic and cathodic reactions unequally. Also, the adsorption of inhibitor molecules reduces the number of electrode reaction sites and thus, inhibition becomes more predominant when the surface is covered with at least a monolayer of inhibitor [15]. However, the degree of coverage of the metal surface by adsorbed inhibitors is often less than equivalent to a monolayer, with the rate of corrosion process reduced by several orders of magnitude.

It has been proposed that organic inhibitors adsorbed on the metal surface change the electrolyte double layer structure and thus affect the electrochemical reactions. In this way, the metal is partly isolated from the corrosion and it is more difficult for the metal atoms to pass from the lattice into the solution as ions [16]. In the present study urea, thiourea and $\mathrm{N}$-allylthiourea are investigated as corrosion inhibitors for silver in $0.1 \mathrm{M} \mathrm{CH}{ }_{3} \mathrm{COOH}$. Also, the effect of solution temperature on the inhibition processes is also studied. The thermodynamic activation parameters were computed and discussed.

\section{EXPERIMENTAL}

The working electrodes employed in the present work were made from a pure silver rod $(99.99 \%$, Koch Light Laboratories, Colnbrook Bucks, England). The electrodes employed in the present work were cut as cylindrical rods welded with $\mathrm{Cu}$-wires for electrical connection and mounted into glass tubes of appropriate diameter using Araldite resin to offer an active flat disc shaped surface of $0.01 \mathrm{~cm}^{2}$ geometric area to contact the test solution. Prior to each experiment the surface pretreatment of the working electrode was performed by mechanical polishing using polishing machine (Model Jean Wirtz TG 200 and TF250, Germany) with successive grades of emery papers, using ethanol as lubricant till reaches the metal surface to a mirror finish. The electrode was then rinsed with acetone, distilled water, and finally dipped in the test solution. Experiments were carried in a three-compartment glass cell. The cell has a double wall jacket through which, water at the adjusted temperature was circulated. A platinum wire was used as an auxiliary electrode. The electrode potential was measured relative to the saturated calomel electrode (SCE) via a salt bridge filled with test solution and whose tip was close to the working electrode. The treated electrode was left into the test solution to attain a steady state free corrosion potential, $\mathrm{E}_{\text {corr }}$. Then, the polarization experiment started stepwise from the corrosion potential where the applied current is increased progressively into anodic direction using a constant power supply (Model 382270 High Precision Quad Output DC Power Supply) and the resulting potentials were recorded.

The anodic-cathodic polarization curves of silver electrode in $0.1 \mathrm{M} \mathrm{CH}_{3} \mathrm{COOH}$ solutions, at $25^{\circ} \mathrm{C}$ were studied. The inhibition efficiency of urea and its derivatives such as, thiourea and allylthiourea as inhibitors for corrosion of $\mathrm{Ag}$ in $0.1 \mathrm{M}$ $\mathrm{CH}_{3} \mathrm{COOH}$ solution was also investigated using Tafel extrapolation technique. Polarization measurements for $\mathrm{Ag}$ in $0.1 \mathrm{M}$ $\mathrm{CH}_{3} \mathrm{COOH}$ in the absence and presence of $0.1 \mathrm{M}$ inhibitor were carried, at $10-50{ }^{\circ} \mathrm{C}$. The solution temperature was controlled within $\pm 1^{\circ} \mathrm{C}$ using an Ultra Thermostat Model 1268-02 (Cole Parmer, USA).

\section{RESULTS AND DISCUSSION}

The anodic-cathodic potentiodynamic polarization curves of silver electrode in $0.1 \mathrm{M} \mathrm{CH}_{3} \mathrm{COOH}$ in the absence and presence of different concentrations of $\mathrm{N}$-allylthiourea is shown by the curves of Fig. 1 , at $25^{\circ} \mathrm{C}$. Similar curves are obtained in presence of thiourea and urea as inhibitors (curves not shown). At all applied current densities, during polarization, the potentials were recorded at regular intervals, starting from steady state conditions. The results show that, in free acid solution and in absence of inhibitor a pronounced effect on the corrosion current density, $\mathcal{J}_{\text {corr }}$, and consequently the anodic dissolution rate of the metal [17-21]. The value of the corrosion current densities were calculated by extrapolating the linear Tafel lines to the respective corrosion potential, $E_{\text {corr. }}$ The anodic corrosion behavior of silver electrode in $0.1 \mathrm{M}$ acetic acid is accompanied by hydrogen evolution reaction on the metal surface. It has suggested that, the corrosion mechanism takes place through the adsorption of undissociated $\mathrm{CH}_{3} \mathrm{COOH}$ molecules and $\mathrm{H}^{+}$ions on the metallic surface [22]. It is generally accepted that hydrogen evolution occurs via the parallel reduction of the free protons and the acetic acid which are already adsorbed on the electrode surface, Eqs 1 and 2 [23, 24]. 

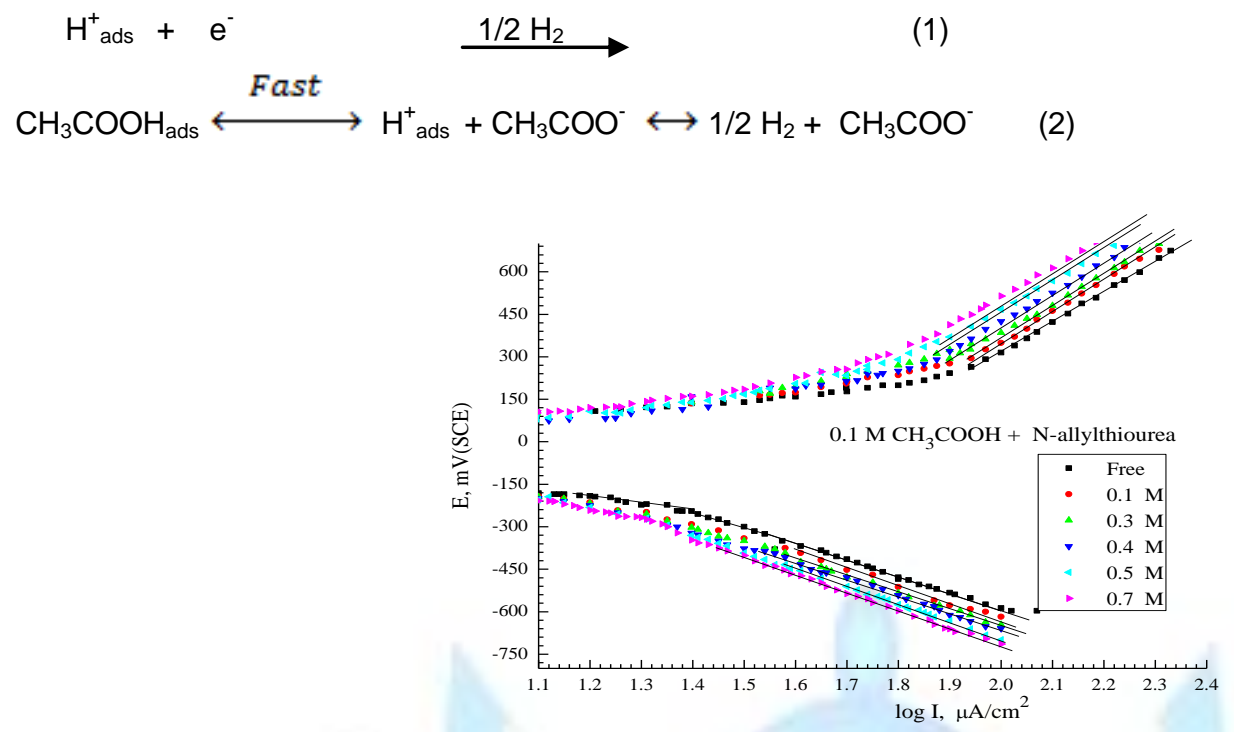

Fig 1. The anodic-cathodic potentiodynamic polarization curves of $\mathrm{Ag}$ in $0.1 \mathrm{M} \mathrm{CH} \mathrm{CH}_{3} \mathrm{COOH}$ in the absence and presence of different concentrations of $\mathrm{N}$-allylthiourea, at $25^{\circ} \mathrm{C}$.

However, from the curves of figure 1 and similar ones, it is clear that, the presence of the organic compounds ( $\mathrm{N}$ allylthiourea, urea and thiourea) cause a decrease in the corrosion rate as evident from the shift of the anodic polarization curves to more positive potentials and the cathodic polarization curves to more negative values. The value of the corrosion current density, $J_{\text {corr }}$, is decreased as the organic additive concentration is increased. This behavior could be attributed to the adsorption of the molecules of these organic compounds or their protonated forms on the metal surface [18, 27-29].

The calculated electrochemical corrosion parameters obtained from the potentiodynamic polarization curves, that is, the corrosion potential, $E_{\text {corr, }}$ anodic Tafel slopes, $b_{\mathrm{a}}$, corrosion current density, $J_{\text {corr, }}$ surface coverage degree, $\theta$, and the inhibition efficiency, $\eta$, in the presence of various concentrations of the used urea derivatives, at $25^{\circ} \mathrm{C}$, are listed in Table 1 .

The surface coverage degree, $\theta$, and the inhibition efficiency, $\eta$, are calculated from:

$$
\begin{array}{ll}
\theta= & {\left[1-\left(J_{\text {corr }} / \mathcal{J}_{\text {corr }}\right)\right]} \\
\eta= & {\left[1-\left(J_{\text {corr }} / \mathcal{J}_{\text {corr }}\right)\right] \times 100}
\end{array}
$$

where $J_{\text {corr. }}$ and $J_{\text {corr }}$ are the corrosion current densities measured in absence and presence of the organic inhibitors, respectively. Inspection of the curves of the curves of Fig. 1 and the like and the kinetic parameters reported in Table 1 reveals the following:

(i)The anodic Tafel slopes, $b_{a}$, decrease while the cathodic Tafel slopes, $b_{c}$ increases with increasing the inhibitor concentration, indicating that, $\mathrm{N}$-allylthiourea, thiourea and urea behaves as mixed inhibitor type[26], they are assumed to block both the anodic and cathodic active sites on the metal surface through adsorption [18,27-29].

(ii) The values of the corrosion potentials, $E_{\text {corr, }}$ change more slowly to less negative direction, while the corrosion current density, $J_{\text {corr }}$, and consequently the corrosion rate decrease with increasing the organic additives concentration.

(iii) The values of the surface coverage degree, $\theta$, and the inhibition efficiency, $\eta$, are markedly increased with increasing the organic additives concentration. This behavior reflects the inhibition action of these additives.

(iv) In presence of constant concentration of the different organic additives e.g. $0.3 \mathrm{M}$, the inhibition efficiency, $\eta$, decrease in the following order: $\mathrm{N}$-allylthiourea > thiourea $>$ urea.

Fig. 2 represents the variation of the corrosion current density, $J_{\text {corr. }}$, of $\mathrm{Ag}$ in $0.1 \mathrm{M} \mathrm{CH} \mathrm{CHOH}_{3} \mathrm{COO}$ in presence of different concentrations of organic inhibitors, versus the inhibitor concentration, $C_{\mathrm{inh}}$, on a double logarithmic scale. The relation between the two variables was given by the equation:

$$
\log J_{\text {corr }}=\alpha_{1}-\beta_{1} \log C_{\text {inh. }}
$$

where $\alpha_{1}$ and $\beta_{1}$ are constants which depend on the inhibitor-type, Table 2. The constant $\alpha_{1}$ represent the corrosion current density at $C_{\text {inh }}=1 \mathrm{M}$. The nearly constant value of lines slopes, $\beta_{1}$, means that the mechanism of corrosion inhibition is nearly the same for the tested compounds. 


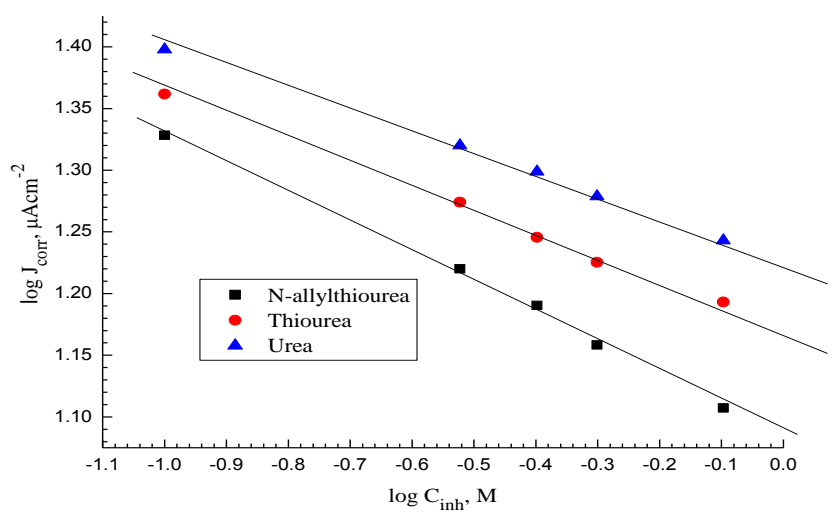

Fig 2.Variation of the corrosion current density, $j_{\text {corr }}$, of $\mathrm{Ag}$ electrode with the inhibitor concentration, $C_{\text {inh, }}$ on a double logarithmic scale.

Table 1. The electrochemical corrosion parameters for $\mathrm{Ag}$ in $0.1 \mathrm{M} \mathrm{CH}_{3} \mathrm{COOH}$ in the absence and presence for different concentrations of organic additives

\begin{tabular}{|c|c|c|c|c|c|c|}
\hline \multirow[t]{2}{*}{ Conc., M } & \multirow[t]{2}{*}{$E_{\text {corr }}, \mathrm{mV}$} & \multicolumn{2}{|c|}{ Tafel slopes V/decade } & $J_{\text {corr, }} A_{c m}^{-2}$ & \multirow[t]{2}{*}{$\theta$} & \multirow[t]{2}{*}{$\eta \%$} \\
\hline & & $b_{\mathrm{a}}$ & $b_{c}$ & & & \\
\hline Free & -290 & 543 & -492 & 30 & -- & -- \\
\hline \multicolumn{7}{|l|}{ Urea } \\
\hline $0.1 \mathrm{M}$ & -230 & 535 & -495 & 25.0 & 0.164 & 16.4 \\
\hline 0.3 & -237 & 546 & -499 & 20.9 & 0.304 & 30.4 \\
\hline 0.4 & -274 & 549 & -503 & 19.9 & 0.338 & 33.8 \\
\hline 0.5 & -303 & 553 & -505 & 19 & 0.368 & 36.8 \\
\hline 0.7 & -304 & 553 & -510 & 17.5 & 0.412 & 41.2 \\
\hline \multicolumn{7}{|l|}{ Thiourea } \\
\hline $0.1 \mathrm{M}$ & 139 & 528 & -501 & 23 & 0.233 & 23.3 \\
\hline 0.3 & -190 & 525 & -503 & 18.8 & 0.373 & 37.3 \\
\hline 0.4 & -330 & 514 & -514 & 17.6 & 0.414 & 41.4 \\
\hline 0.5 & -370 & 506 & -525 & 16.8 & 0.441 & 44.1 \\
\hline 0.7 & -370 & 505 & -535 & 15.6 & 0.486 & 48.6 \\
\hline \multicolumn{7}{|c|}{ N-Allylthiourea } \\
\hline $0.1 \mathrm{M}$ & -329 & 525 & -513 & 21.3 & 0.293 & 29.3 \\
\hline 0.3 & -303 & 524 & -517 & 16.6 & 0.447 & 44.7 \\
\hline 0.4 & -370 & 522 & -520 & 15.5 & 0.485 & 48.5 \\
\hline 0.5 & -340 & 520 & -526 & 14.4 & 0.520 & 52.0 \\
\hline 0.7 & -304 & 518 & -528 & 12.8 & 0.574 & 57.4 \\
\hline
\end{tabular}


Table 2. The values of the constants $\alpha_{1}$ and $\beta_{1}$ of Eq. 5 .

\begin{tabular}{lcc}
\hline Inhibitor & $\alpha_{1}, \mu \mathrm{Acm}^{-2} \mathrm{M}^{-1}$ & $\beta_{1}, \mu \mathrm{A} \mathrm{cm} \mathrm{M}^{-1}$ \\
\hline N-allylhiourea & 1.087 & -0.222 \\
Thiourea & 1.170 & -0.188 \\
Urea & 1.225 & -0.182 \\
\hline
\end{tabular}

\section{Effect of Temperature}

The effect of temperature, $15-40^{\circ} \mathrm{C}$, on the anodic-cathodic potentiodynamic polarization curves of $\mathrm{Ag}$ in $0.1 \mathrm{M}$ $\mathrm{CH}_{3} \mathrm{COOH}$ was further investigated. The data indicated that, raising the solution temperature caused an increase in both the anodic and cathodic current densities, and the polarization curves were shifted into the more active direction. This means that, the rise in solution temperature enhances the rate of both the cathodic and the anodic reactions [18].

Also, the effect of temperature on the potentiodynamic polarization curves of $\mathrm{Ag}$ in $0.1 \mathrm{M} \mathrm{CH}_{3} \mathrm{COOH}$ in presence of 0.1 $\mathrm{M}$ of different inhibitors ( $\mathrm{N}$-allylthiourea, urea and thiourea) are carried (curves not shown). The data indicated that, the temperature has a clear effect on the general shape of the polarization curves. It is found that, the corrosion current density, $J_{\text {corr }}$, increases with increasing the solution temperature, $T$, in kilven scale, both in uninhibited and inhibited solutions. The relation between the corrosion current density, $J_{\text {corr, }}$ and temperature, $T$, is shown in Fig. 3 , and can be represented by the following equation:

$$
J_{\text {corr. }}=\alpha_{2}+\beta_{2} T
$$

where $\alpha_{2}$ and $\beta_{2}$ are constants depend on the type of the test solution (Table 3). The constant $\alpha_{2}$ represent the corrosion current density at absolute temperature. The nearly constant values of lines slopes, $\beta_{2}$, means the mechanism of dissolution of silver electrode doesn't change by inhibitor additions, it is nearly the same for the tested compounds.

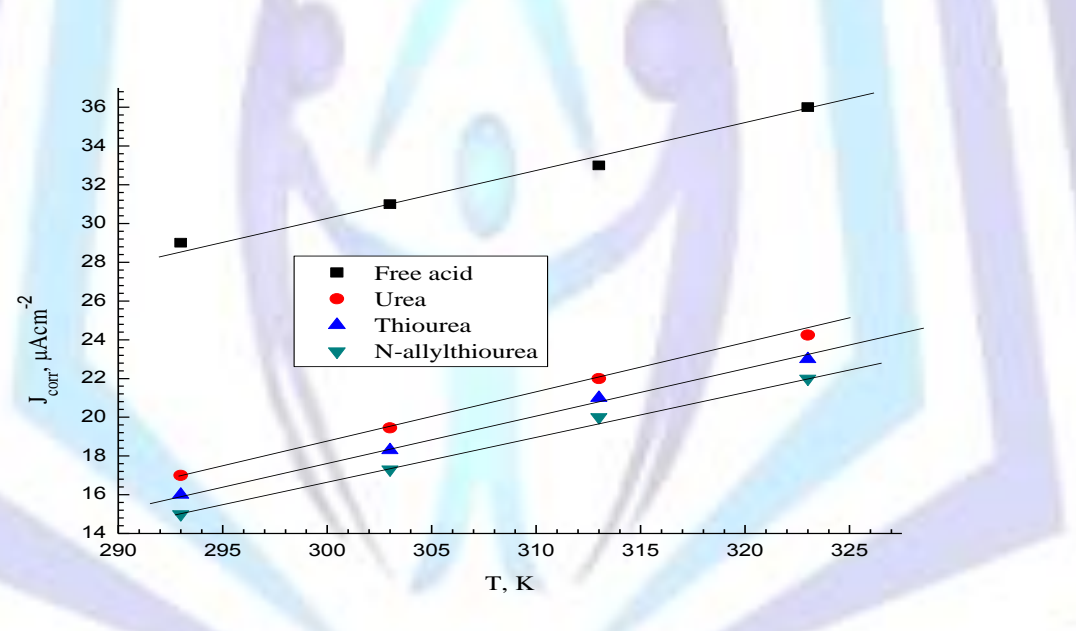

Fig 3. Variation of the corrosion current density, $J_{\text {corr }}$, with the solution temperature, $T$.

Table 3. The values of the constants $\alpha_{2}$ and $\beta_{2}$ of Eq. (6).

\begin{tabular}{lcc}
\hline Inhibitor & $\alpha_{2}, \mu \mathrm{Acm}^{-2} \mathrm{M}^{-1}$ & $\beta_{2}, \mu \mathrm{A} \mathrm{cm}^{-2} \mathrm{M}^{-1}$ \\
\hline Free & -44.92 & 0.250 \\
Urea & -56.27 & 0.250 \\
Thiourea & -57.32 & 0.250 \\
N-allylhiourea & -57.43 & 0.245 \\
\hline
\end{tabular}




\section{Activation Energy}

The apparent activation energy, $\Delta E^{*}$, of the corrosion reaction was determined using Arrhenius plots. Arrhenius equation could be written as [28]:

$$
J_{\text {corr }}=A \exp \left(-\Delta E^{*} / R T\right)
$$

where $J_{\text {corr }}$ is the corrosion current density, $\mathrm{A}$ is the Arrhenius pre-exponential constant, $\Delta E^{*}$ is the apparent activation energy, $\mathrm{R}$ is the universal gas constant and $T$ is the absolute temperature. Arrhenius plots (i.e., logarithm $J_{\text {corr }}$ against $1 / T$ ) can be plotted in Fig. 4. Straight lines, with coefficients of correlation very close to unity are obtained for $0.1 \mathrm{M} \mathrm{CH} \mathrm{COOH}_{3}$ in absence and presence of $0.1 \mathrm{M}$ inhibitors. The calculated value of $\Delta E^{*}$ for dissolution reaction of $\mathrm{Ag}$ in $0.1 \mathrm{M} \mathrm{CH} \mathrm{COOH}_{3}$ is $13.84 \mathrm{~kJ} \mathrm{~mol}^{-1}$. This value is nearly consistent with the data obtained by Martinez et al. [21]. The values of the activation energy, $\Delta E^{*}$, in presence of inhibitors, urea, thiourea and allylthiourea are $21.51,22.22$ and $23.47 \mathrm{kJmol}^{-1}$, successively, Table 4. The relatively higher values of $\Delta E^{*}$ in presence of the organic additives compared to that in free acid are interpreted as an indication of physi-sorption process on silver electrode surface[32]. An Alternative form of Arrhenius [28] equation is transition state equation:

$$
J_{\text {corr }}=\mathrm{R} T / \mathrm{Nh} \exp \left(\Delta S^{*} / \mathrm{R}\right) \exp \left(-\Delta H^{*} / \mathrm{R} T\right)
$$

where $\mathrm{h}$ is Plank's constant $6.6261 \times 10^{-34}, \mathrm{~N}$ is the Avogadro's number $6.0225 \times 10^{23} \mathrm{~mol}^{-1}, \Delta \mathrm{S}^{*}$ is the entropy of activation and $\Delta H^{*}$ is the enthalpy of activation. Fig. 5 shows a plot of $\log \left(J_{\text {corr }} / T\right)$ against $1 / T$ for $\mathrm{Ag}$ in $0.1 \mathrm{M} \mathrm{CH} \mathrm{COOH}_{3}$ in the absence and presence of $0.1 \mathrm{M}$ of organic inhibitors. Straight lines, with correlation coefficients approach to 1 are obtained, with slope $\left(-\Delta H^{*} / 2.303 \mathrm{R}\right)$ from which the values of $\Delta H^{*}$ can be calculated, Table 4 . From the intercept of log $\left(J_{\text {corr }} / T\right)-$ axis the entropy of activation $\Delta S^{*}$ can be calculated (Table 4). The positive signs of enthalpies $\Delta H^{*}$ reflect the endothermic nature of dissolution process of $\mathrm{Ag}$. The large negative values of entropy of activation $\left(\Delta S^{*}\right)$ implies that the activated complex is the rate determining step represents an association rather than dissociation, resulting in a decrease in randomness on going from the reactants to the activated complex [32].
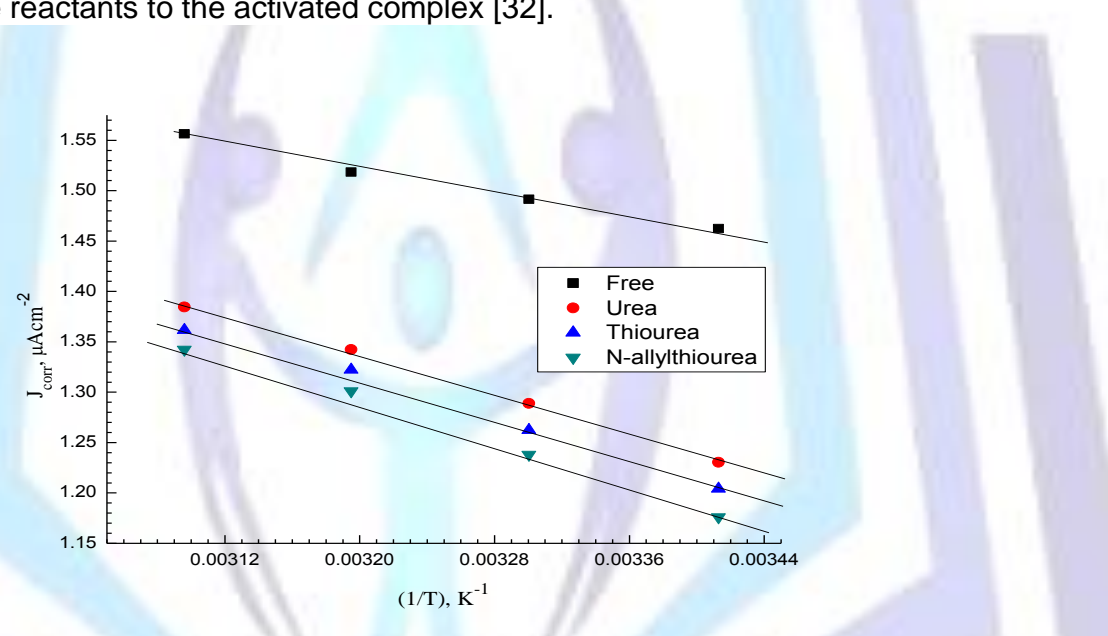

Fig. 4. Arrhenius plots (logarithm $J_{\text {corr }}$ against $1 / T$ ) for $\mathrm{Ag}$ in $0.1 \mathrm{M} \mathrm{CH}_{3} \mathrm{COOH}$ in the absence and presence of $0.1 \mathrm{M}$

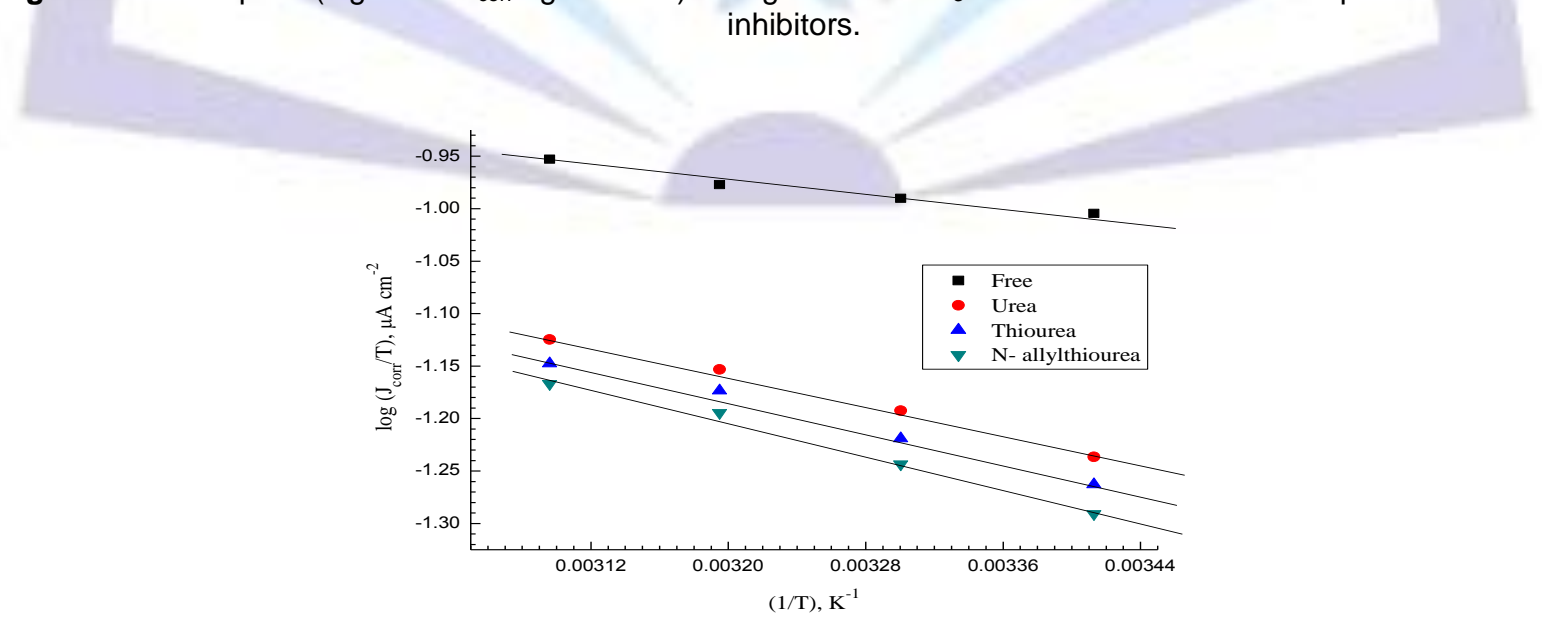

Fig 5. A plot of log $\left(J_{\text {corr }} / T\right)$ against $1 / T$ for $\mathrm{Ag}$ in $0.1 \mathrm{M} \mathrm{CH}_{3} \mathrm{COOH}$ in the absence and presence of $0.1 \mathrm{M}$ of inhibitors. 
Table.4. The values of thermodynamic parameters of activation of anodic dissolution of silver in $0.1 \mathrm{M} \mathrm{CH}{ }_{3} \mathrm{COOH}$ in absence and presence of $0.1 \mathrm{M}$ inhibitor.

\begin{tabular}{lccc}
\hline Solution & $\Delta \mathrm{E}^{*}, \mathrm{~kJ} / \mathrm{mole}$ & $\Delta \mathrm{H}^{*}, \mathrm{k} \mathrm{J} / \mathrm{mole}$ & $\Delta \boldsymbol{S}^{*}, \mathrm{~J} / \mathrm{mole}$ \\
\hline Free acid & 13.84 & 3.03 & -206.2 \\
Urea & 21.51 & 6.80 & -197.8 \\
Thiourea & 22.22 & 7.22 & -196.2 \\
Allylthiourea & 23.47 & 7.64 & -195.7 \\
\hline
\end{tabular}

\section{Adsorption Isotherm}

The action of an inhibitor in aggressive acid media is assumed to be due to its adsorption at the metal/solution interface. The adsorption process depends on the electronic characteristics of the inhibitor, the nature of metal surface, temperature, steric effects and the varying degrees of surface-site activity [32]. In fact, the solvent $\mathrm{H}_{2} \mathrm{O}$ molecules could also be adsorbed at the metal/solution interface.

However, the inhibition by nitrogen-containing compounds is primarily due to the adsorption of these compounds at the metal surface, and the greater adsorption, the greater inhibition. The surface of the electrode in aqueous solution is considered to be covered with water dipoles. Therefore, for inhibition to occur, a quasi-substitution process between the organic molecules in the aqueous phase, Org (aq.) and water molecules at the electrode surface $\mathrm{H}_{2} \mathrm{O}_{(\mathrm{s})}[33,34]$.

$$
\operatorname{Org}_{(\text {aq. })}+\mathrm{x} \mathrm{H}_{2} \mathrm{O}_{(\mathrm{s})} \leftrightarrow \operatorname{Org}_{(\mathrm{s})}+\mathrm{n} \mathrm{H}_{2} \mathrm{O}_{(\text {aq. })}
$$

where $\operatorname{Org}_{(\text {(aq.) }}$ and $\mathrm{H}_{2} \mathrm{O}_{\text {(s) }}$ are the organic molecules and water molecules in the aqueous solution, respectively. $\mathrm{x}$, the size ratio representing the number of water molecules replaced by one molecule of organic adsorbate.

It is widely acknowledge that, adsorption isotherms provide useful insight into the mechanism of corrosion inhibition. Often, the most frequently use adsorption isotherms are Langmuir, Temkin, Frumkin, Hill de Boer, Parsons, Flory-Huggins and Dhar-Flory-Huggins and Bockris-Swinkel [35]. All isotherms are often of the general form:

$$
f(\theta, \mathrm{x}) \exp (-2 \mathrm{a})=\mathrm{K}_{\mathrm{ads}} \mathrm{C}
$$

where $f(\theta, x)$ is the configurational factor (heterogeneous factor of the metal surface) which depend upon the assumptions underlying the derivation of the isotherm, and gives the variation of adsorption energy with the coverage [2730]. $\theta$ is the surface coverage, $a$ is the attraction constant, $x$ is the size ratio, $K_{\text {ads }}$ is the adsorption equilibrium constant of the adsorption process, and $C$ is the inhibitor concentration in the electrolyte.

Attempts were made to fit the values of $\theta$ for each inhibitor varied at constant temperature with the concentration, $C$, of the inhibitor to various known adsorption isotherms. The best fit was conformed to Temkin adsorption isotherm. The Temkin isotherm characterizes the adsorption of uncharged molecules on a heterogeneous surface, where $\theta$ is a linear function of $\ln C[36]$.

$$
\theta=(1 / f) \quad \ln \mathrm{K}_{\mathrm{ads}} C
$$

A plot of $\theta$ values against the corresponding values of $\log C$, Fig 6 , was found to be linear, provide that the assumptions of the Temkin model isotherm are valid. The calculated values of the adsorption parameters $f$ and $K_{\text {ads }}$ are shown in Table 6 . The standard free energy of adsorption, $\Delta \mathrm{G}^{\circ}$ ads was calculated from equilibrium constant using the following equation [37].

$$
\mathrm{K}=1 / 55.5 \exp \left(-\Delta \mathrm{G}^{\circ} \text { ads } / \mathrm{RT}\right)
$$

The $\Delta \mathrm{G}^{\circ}$ ads values for all inhibitors are present in Table 5. The negative values of $\Delta \mathrm{G}^{\circ}$ ads imply that the adsorption of urea and its derivatives on the metal surface is allowed from thermodynamics point of view and indicated that the inhibitor is strongly adsorbed.

Table.5. Linear correlation coefficient, $R^{2}$, and the adsorption parameters, $f, K, \Delta G^{\circ}$ for $\mathrm{Ag}$ in $0.1 \mathrm{M} \mathrm{CH} \mathrm{COOH}_{3}$ in absence and presence of $0.1 \mathrm{M}$ inhibitor.

\begin{tabular}{ccccc}
\hline Solution & \multicolumn{1}{c}{$R^{2}$} & $f$ & $K, \mathrm{~mol}^{-1}$ & $\Delta G^{\circ}, \mathrm{k} \mathrm{J} / \mathrm{mole}$ \\
\hline Urea & 0.999 & 7.86 & 36.0 & -18.83 \\
Thiourea & 0.997 & 7.70 & 60.3 & -20.11 \\
Allylthiourea & 0.998 & 7.0 & 76.6 & -20.80
\end{tabular}




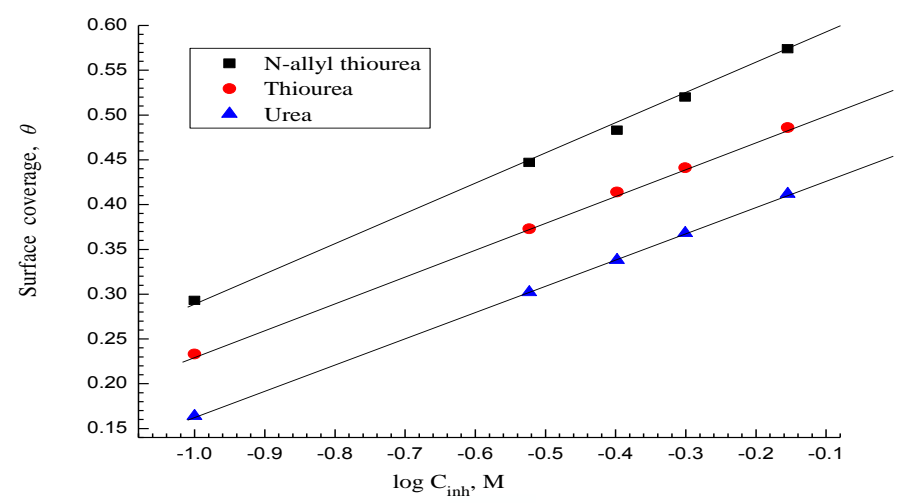

Fig 6. Temkin adsorption isotherm for $\mathrm{Ag}$ in $0.1 \mathrm{M} \mathrm{CH} \mathrm{CHOH}_{3} \mathrm{CO}$ the absence and presence of $0.1 \mathrm{M}$ of organic inhibitors.

\section{Mechanism of Inhibition:}

Among the effective corrosion inhibitors, organic compounds containing one or more polar functions groups (with $\mathrm{N}$, $\mathrm{O}$ and $\mathrm{S}$ atoms ) have shown to be quite efficient to prevent corrosion [38,39], in addition to heterocyclic compounds containing polar groups and $\pi$ electrons [40]. The inhibition action of these organic compounds is usually attributed to interactions with metallic surfaces by adsorption. The polar function is frequently regarded as the reaction center for adsorption process established [41]. The adsorption bond strength is determined by the electron density and polarizability of the functional group [42]. The inhibition efficiency of homologous series of organic substances, differing only in hetero atoms, is usually in the following sequence: $P>S e>S>N>O[42,43]$. Every and Riggs [44] reported that mixtures of nitrogen and sulphur compounds are often better than either type alone.

In this study, a series of organic nitrogen containing compounds such as urea, and N-allylthiourea. Referring to the curves of theses inhibitors and the values reported in Table 1 indicates that the surface coverage, $\theta$, and the inhibition efficiency, $\eta$, of the compounds of the group increases in the following orders: urea $<$ thiourea $<\mathrm{N}$-allylthiourea.

Urea was previously used as corrosion inhibitor for copper [12], brasses in $\mathrm{HNO}_{3}$ [12,13], $\mathrm{Al}$ in $\mathrm{HCl}$ [45]and $\mathrm{Ni}$ in alkaline medium [14]. For copper and brasses [12,13], urea was found to be a cathodic type inhibitor. In alkaline medium, urea behaves bifunctionally, inhibiting pitting corrosion of $\mathrm{Ni}$ when present in low concentrations and promotes corrosion at higher concentrations. The inhibiting effect of urea was assumed to be due to the formation of a Ni-urea complex [14]. However, in acid solutions urea behaves as a mono acidic base $\left[\mathrm{H}_{2} \mathrm{~N}-\mathrm{C}(\mathrm{OH})-\mathrm{NH}_{2}\right]^{+}$(I) which in presence of acetate ions could form the acetate salt base $\quad\left[\mathrm{H}_{2} \mathrm{~N}-\mathrm{C}(\mathrm{OH})-\mathrm{NH}_{2}\right]^{+} \mathrm{CH}_{3} \mathrm{COO}^{-}$, (II). However, the inhibition action of urea towards the corrosion of $\mathrm{Ag}$ in $0.1 \mathrm{M} \mathrm{CH}_{3} \mathrm{COOH}$ solutions could be attributed to the precipitation of the acetate salt (II) on Ag surface as well as the adsorption of the cationic species (I) on the cathodic sites of the metal surface. From Table 1 , the anodic Tafel slopes $\left(\beta_{a}\right)$ is affected in presence of urea and other used these compounds, therefore, it is assumed to act as an anodic inhibitor, and inhibition of the corrosion of $\mathrm{Ag}$ in $\mathrm{CH}_{3} \mathrm{COOH}$ solutions takes place by the precipitation of the acetate salt on the anodic sites of the metal surface.

Thiourea (TU) has been recommended before as inhibitor for dissolution of metals in acid media [46-48]. It has been also used as a restrainer in the descaling and pickling baths [49]. This compound is specifically adsorbed on the metal surface when present in low concentrations [46, 47]. It affects the partial cathodic reaction [50], the partial anodic reaction [51] or both [52], depending on the type of metal and solution composition. However, when present in higher concentrations, TU behaves as corrosion promoter rather than corrosion inhibitor $[47,48]$. Thiourea acts as corrosion inhibitors when present in lower concentrations via an adsorption mechanism. It is assumed that the primary adsorption of TU on the metal surface causes the retardation of dissolution. This occurs until the bulk concentration of the additive allows the formation of an adsorption monolayer [48]. This layer acts in one way or the other, as a bridge between the metal and the incoming TU molecules, which facilitates their reduction to $\mathrm{HS}^{-}$and/or $\mathrm{S}^{2-}[47,53]$.

$$
\left(\mathrm{NH}_{2}\right)_{2} \mathrm{CS}+9 \mathrm{H}^{+}+6 \mathrm{e} \rightarrow \mathrm{H}_{2} \mathrm{~S}+\mathrm{CH}_{3}{ }^{+}+2 \mathrm{NH}_{4}{ }^{+}
$$

At the same time thiourea, TU, and its derivatives $\mathrm{N}$-allylthiourea like other adsorption inhibitors are known to undergo specific adsorption, i.e. they are adsorbed in the inner part of the electrical double layer. The protonated products of these compounds III and IV and perhaps some of their reduction products would also undergo specific adsorption [47].

$$
\mathrm{H}_{2} \mathrm{~N}^{-} \mathrm{C}=\mathrm{S}+\mathrm{H}^{+} \longrightarrow\left[\begin{array}{l}
\mathrm{H}_{2} \mathrm{~N} \\
\mathrm{H}_{2} \mathrm{~N}^{-} \mathrm{C}-\mathrm{SH}
\end{array}\right]^{+}
$$


<smiles>C=CCNC(N)CCCC</smiles>

These protonated species are assumed to replace some of the $\mathrm{H}_{3} \mathrm{O}^{+}$ions from the outer Helmholtz plane. The process limits the accessibility of the surface to the reacting $\mathrm{H}_{3} \mathrm{O}^{+}$ions and thus blocks part of the metallic surface and hence decreases the corrosion rate. Specific adsorption modifies the structure of the electrical double layer and affects the Zeta potential and the apparent activation energy [47]. A species which decreases the Zeta potential, i.e., increases the apparent activation energy and thus decreases the reaction rate, i.e., acts as corrosion inhibitors [54], replace some of $\mathrm{H}_{3} \mathrm{O}^{+}$ions from the outer Helmholtz plane [47]. This causes a decrease of the accessibility of the surface to the reacting $\mathrm{H}_{3} \mathrm{O}^{+}$ions. The additives are assumed to block part of the surface and hence decrease the reaction rate with a consequence increase in the inhibition efficiency.

The decrease in the inhibition efficiency of the studied inhibitors urea, thiourea and $\mathrm{N}$-allylthiourea, follow the order: urea $<$ thiourea < N-allylthiourea, could be explained on the basis of action of these organic species on the transition of metal/solution interface from a state of active dissolution to the passive state. This can be attributed to the adsorption of the inhibitor species on the metal surface forming a protective film. A process which depends on various factors among which:

(i) The electrostatic forces between ionic charges or dipoles of the adsorbed species and the electric charge on the metal surface.

(ii)The formation of a coordinate type of link between the inhibitor species and the metal surface via the electron transfer from the adsorbed species to the vacant electron orbital of low energy in the metal [54]. Therefore, the decreased efficiency of the studied additives in the sequence: urea < thiourea < N-allylthiourea, could be attributed to:

1- The increased degree of surface coverage which is always larger with urea derivatives than with the base urea molecules. This is due to the fact that volume or the area of the derivatives molecules becomes larger than urea molecules.

2-The change in the orientation of the adsorbed species which is likely to be different, due to different charge distribution on the urea and derived species of thiourea and $\mathrm{N}$-allylthiourea.

\section{CONCLUSIONS}

From the potentiodynamic polarization study of $\mathrm{Ag}$ in $0.1 \mathrm{M} \mathrm{CH} \mathrm{CH}_{3} \mathrm{COOH}$ in the absence and presence of different concentrations of urea, thiourea and $\mathrm{N}$-allylthiourea the following conclusion could be drawn:

- The presence of the organic inhibitors cause a decrease in the corrosion rate as evident from the shift of the anodic polarization curves to more positive potentials and the cathodic polarization curves to more negative values.

- The value of the corrosion current density, $\mathrm{J}_{\text {corr }}$, is found to depend on the inhibitor-type and is decreased as inhibitor concentration is increased.

- The inhibition is attributed to adsorption of the inhibitor molecules on silver surface. According to Temkin adsorption isotherm.

- The inhibition efficiency increases in the order: Urea $<$ thiourea $<\mathrm{N}$-allylthiourea

\section{REFERENCES}

[1] Benali O., Larabi L., Tabti, B., Harek, Y. (2005) Anti-Corros. Method Mater 52, 280-285.

[2] Fouda A.S, Al-Saraway A.A., El Katori E. E. (2006) Desalination, 201, 1-13.

[3] Al-Sarawy A.A., Fouda A.S., Shehab El-Dein W.A. (2008) Desalination 229, 279- 293.

[4]Prabhu R.A., Venkatesha T.V., Shanbhag A.V., Praveen B.M. Kulkarni G.M., Kalkhambkar R.G. (2008) Mater. Chem. Phys. 108, 283- 289.

[5] Olivares O., Likhanova N.V.,Gomez B., Navarrete J., Lianos-Serrano M.E., Arce E., Hallen J.M. (2006) Appl. Surf. Sci. 252, 2894-2909.

[6] Trasatti S. (1992) Electrochim. Acta 37, 2137-2144.

[7] Popova A., Sokolova E., Raicheva S., Christov M., (2003) Corros. Sci., 45, 33-58.

[8] Lagrenee M., Mernari B., Bouanis M., Traisnel M. Bentiss F. (2002) Corros. Sci. 44, 573-588.

[9] Tamil Selvi S., Raman V. and Rajendran N. (2003). Appl. Electrochem., 33, 1175-1182.

[10] Benabdellah M., Benkaddour M., Hammouti B., Bendahhou M., Aouniti A. (2006) Appl. Surf. Sci. 252, 6212-6217. 
[11] Olivares-Xometl O., Likhanova N.V., Domínguez-Aguilar M. A., Arce E., Dorantes H., Arellanes-Lozada P. (2008) Mater. Chem. Phys. 110, 344-351.

[12] Putilova. I. N., Balezin. S. A. and Barannik. V.P., Metallic Corrosion Inhibitors, Pergamon, (1960).

[13] Desai. M. N., Sahah. V.K., Transactions of Saest, 7 (1972) 153-155.

[14] Abd El Haleem S. M., Abd El Wanees S. (2011) Mater. Chem. Phys. 128, 418.

[15] Abd El Wanees S., (1994) Anti-Corrosion Methods Mater, 41, 3-7.

[16] J. L. Rosenfeld, Corrosion Inhibitors (NewYork, Mc.Graw- hill, (1981) p.327.

[17] Abd El Aal E. E., Zakria W., Diab A, Abd El Haleem S. M. (2003) J. Mateials Engineering and performance, 12, 172178(7).

[18] Chin R. J., Nobe K. (1972) J. Electrochem. Soc. 119, 1457-1461.

[19] Stern M., Geary A.L. (1956) J. Electrochem. Soc., 104, 56-63.

[20] El-Taib Heakal F., Fekry A. M. Ghoneim, A.A. (2008) Corros. Sci. 50, 1618-1626.

[21] Martinez L.L., Segarra M., Fernandez M., Espiell F. (1993) Meturgical Transactions 24, 827-837.

[22] Veloz M. A., González I., Electrochim. Acta 48 (2002) 135.

[23] Garsany Y., Pletcher D., Hedges B (1984) J. Electroanal. Chem.538-539, 285.

[24] Albery W. J., Bell R. P., Proc. Chem. Soc., (1963) 169.

[25] Vracar Lj., Drazic D. M. (1992) J. Electroanal. Chem. 339, 269.

[26] Pyun S-I., Moon S-M. (1999) J. Solid State Electrochem., 3, 331.

[27] Popova A. (2007) Corros. Sci. 49, 2144- 2158.

[28] Chetouani A., Daoudi, Hammouti M. B., Ben Hudda T., Benkaddour M. (2006) Corros. Sci. 48, $2987-2997$.

[29] Abd El Nabay B.A., Kamis E., Ramadan M.S., El Gindy A. (1996) Corrosion, NACE 52, 671- 679.

[30] E. Khamis, F. Bellucci, R.M. Latanision, E.S.H. El Ashry, Corrosion, NACE 47(1991) 677.

[31] Frignani A., Moticelli, C., Trbanelli, G. (1998) Br. Corros. J., 3371.

[32] Umoren S. A., Ebenso, E.E (2007) Mater Chem. Phys, 106, 387-393.

[33 ] Moretti G., Quartanone G., Tassan A. and A. Zingales, (1994) Werkst.Korros. 45, 641 - 647.

[34] Ashassi-Sorkhabi H., ghalebsaz-Jeddi N. (2005) Mater. Chem. Phys 92, 480-486.

[35] Bockris, O'M., Swinkels D. A. J. (1964) J. Electrochem. Soc. 111, 736.

[36] Morad M. S., Kamel El-Dean AQ.M. (2006) Corros. Sci. 48, 3398-3412.

[37] Bentiss F., Lebrini M., Lagrenee M. M. (2005) Corros. Sci 47, 2915

[38]Hosseini S. M. A., Azimi. A. (2009) Corros. Sci. 51, 728-732.

[39]Dean S. W., Derby R., Vondembussche G. T., Inhibitor Types, Mater. Perform. 20 (1981) 47.

[40]Riggs O. L., jr., Corrosion Inhibitors, second edition, C. C. Nathan, Houston, TX, (1973).

[41]Stoyanova A. E., Peyerimhoff. S. D. (2002) Electrochem. Acta 47, 1365-1371.

[42] El-Shafei.A. A., Moussa M. N., El-Far A.A.(2001) Mater. Chem. Phys. 70 175-180.

[43]Hackaman. N. and Hard. R., Proc. First International Congress on Metallic Corrosion, Butterworths, London (1962) p.166.

[44]Every R. L., Riggs. O. L., (1964) Mater Prot. 3, 46.

[45] Abd El Haleem S. M., Abd El Wanees S., Abd El Aal E. E., Farouk. A. (12013) Corros. Sci. 68, 1-13

[46]Ateya B.G., El-Anadouli B. E., El-Nizamy F. M. (1984) Corros. Sci. 24497-507.

[47] Ateya B. G., Anadouli B. E. and El-Nizamy F. M. (1984) Corros. Sci. 24 509-515.

[48] Shams El Din. A. M., Elhosary A. A., Saleh R. M., Abd El Kader J. M. (1977) Werkst. Korros. 28, 26-31.

[49] Janic T. and Necakov V., Zast. (1970) Mater. 172102884.

[50] Vasantasree V. and Rama Char T. L. (1966) J. Electrochem. Soc., India, 1571.

[51] Ross T. K., Jones D. H., Ann. Univ. Ferrara, Sez.5 Suppl. 3 (1960) 63 (publ.1961). 
[52]Ammar L. A., Khorafi F. M. (1973) Metalloberfl 27, 14.

[53] Cavallaro L., Felloni L., Trabanelli G., Pulideri F. (1963) Electrochim. Acta, 8, 521.

[54] Rozenfeld I. L., in Corrosion Inhibitors, McGraw-Hill, New York (1981) p. 98.

[55] Migahed M. A., Nassar I. F. (2008) Electrochem. Acta, 53- 2877. 